\author{
تأثير تنش كم آبى بر ترشح گلومالين توسط قارجهاى گلومرال همزيست با گياه ذرت \\ مرضيه ريش سفيد،'" ناصر على اصغرزاد' و محمدرضا نيشابورى

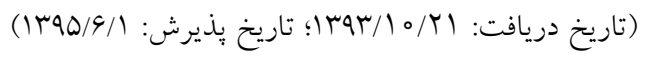

جكيده

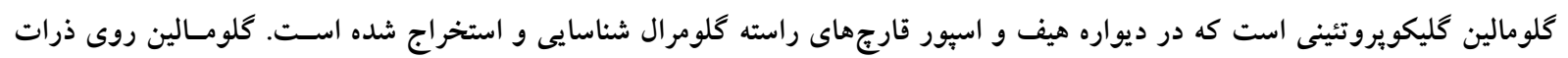

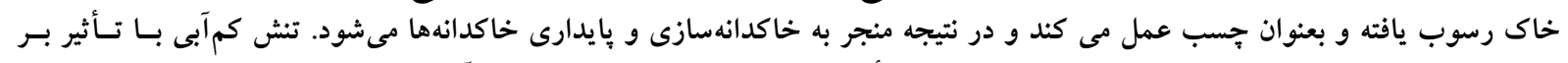

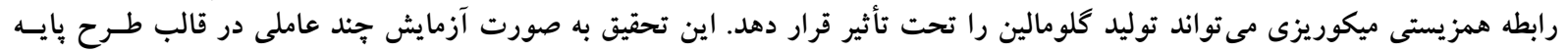

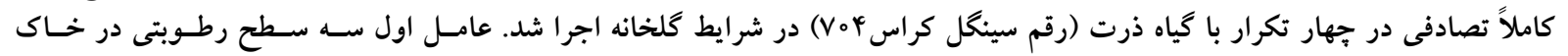

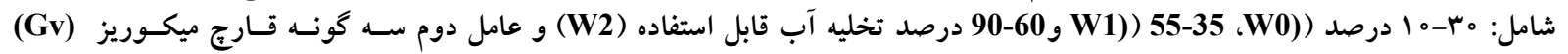

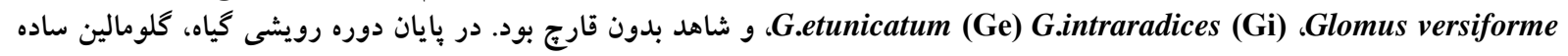

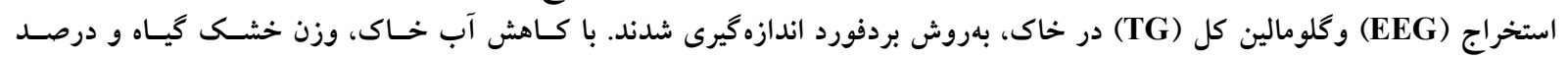

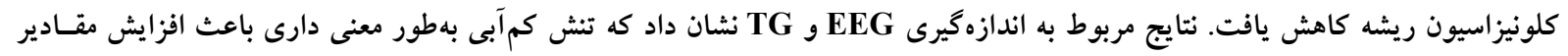
و و EEG

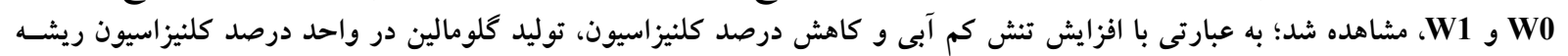
افزايش يافت.

وازههاى كليدى: تنش كمآبى، ديناميك كربن، ذرت، قارجهاى كلومرال، كلومالين

1. كروه علوم خاك، دانشكده كشاورزى، دانشخاه تبريز

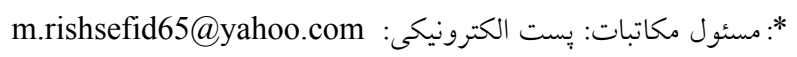


محيطهاى خشك و نيمه خشك كاهش مى يابد (Yo). رولــدن

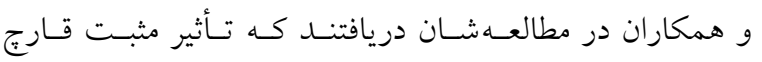

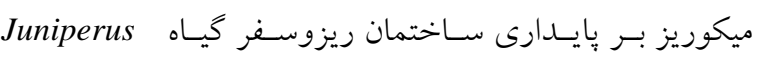
oxycedrus

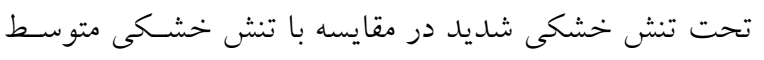

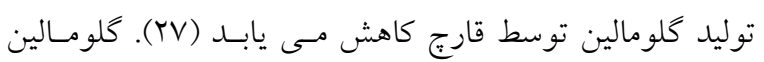

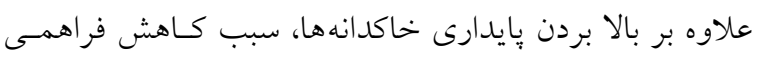

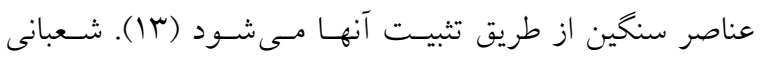

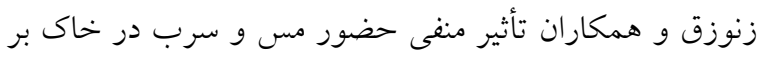

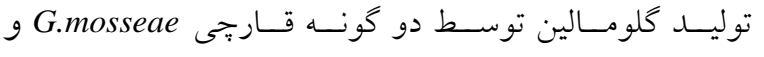
G.intraradices

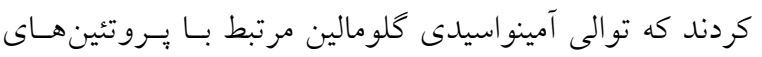

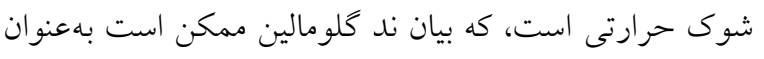

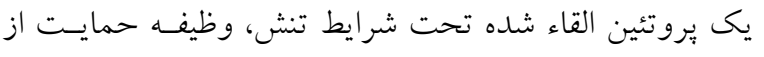

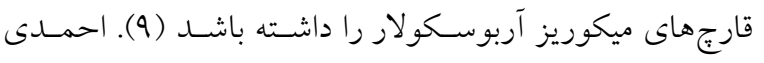

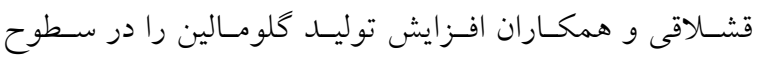
شورى بالا عليرغم كاهش درصد كلنيزاسيون ريشه كيـاه ذرت

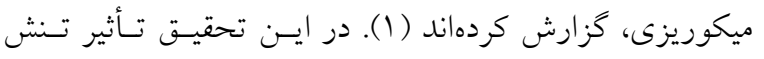

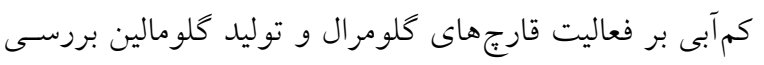

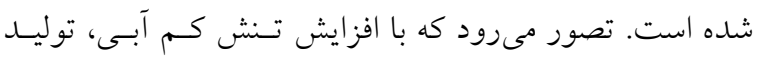

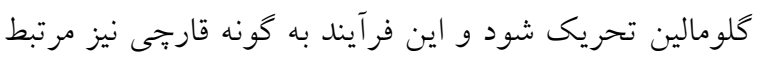

باشد.

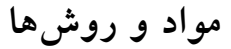

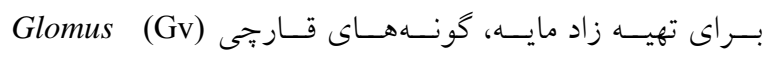
(در G.etunicatum (Ge) و G.intraradices (Gi) vversiforme

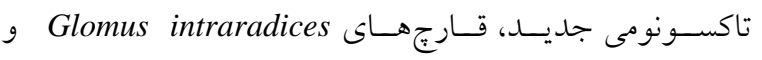
Rhizophagus irregularis به ترتيب بـ Glomus etunicatum

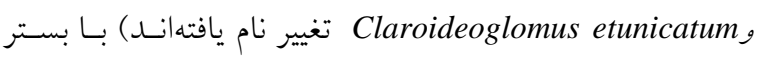
خاك استريل و با ميزبان كياهى ذرت تلقيح شـده و در شـرايط

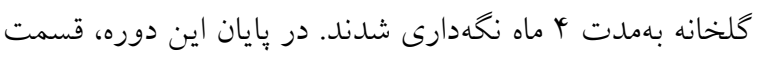
هو ايى كياه ذرت از سطح خاك قطع شـــه و محتويـات داخـل
در منــاطق خشـك و نيمسهخشـى، افـزايش شـــت خشكى مى تواند بهعلت افزايش غلظت دى اكسيدكربن تحـت الخــوى

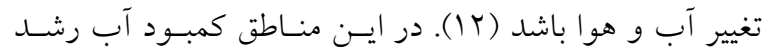

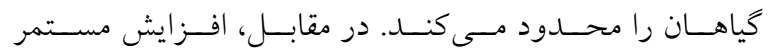
دى اكسيدكربن اتمسـفرى ممكـن اسـت توليــ زيسـت تـودهـ كياهى را تحريك كند(0) كرئ كربن آلى خاك عامل اصلى تعيين

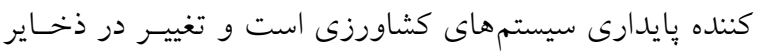

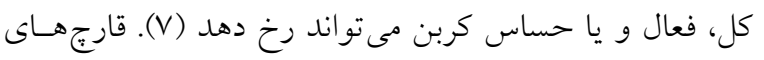
ميكوريز آربوسكولار (Arbuscular mycorrhiza) داراى رابطه فئه

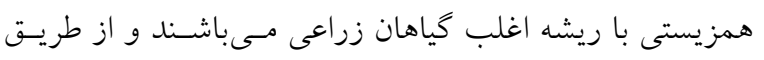

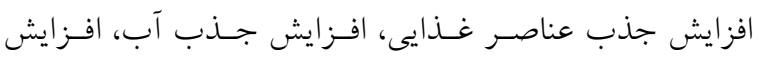

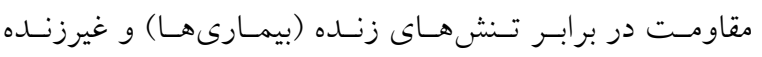

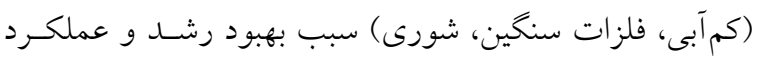

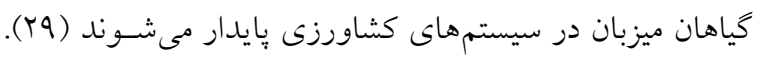

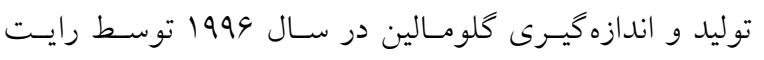

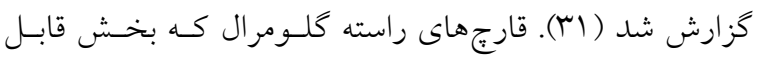

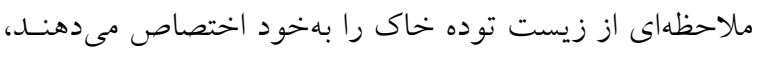

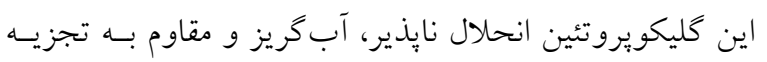

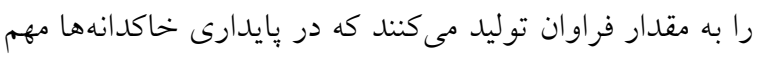

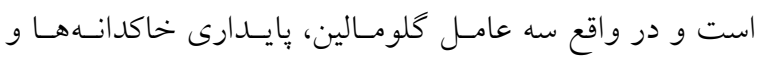

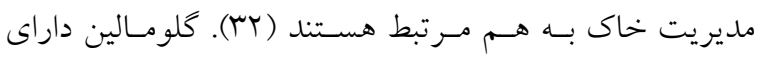
كربن و نيتروزن است و بخـش قابـل تـوجهى از منبـع كـربن

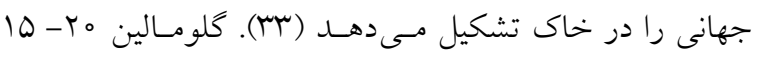

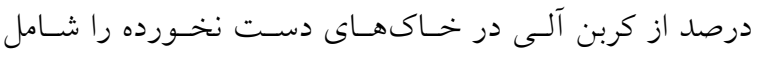

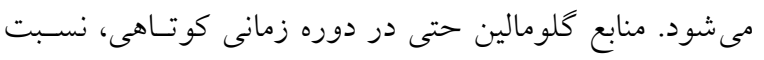

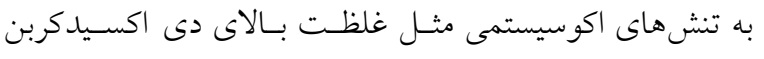

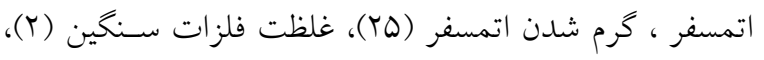

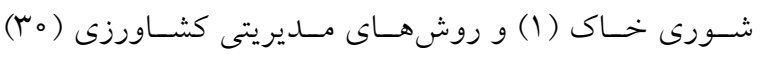

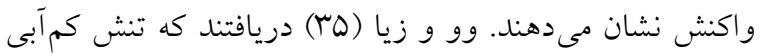

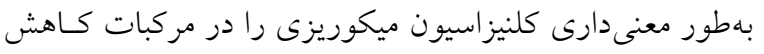

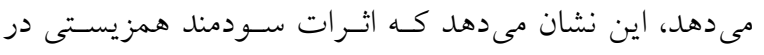




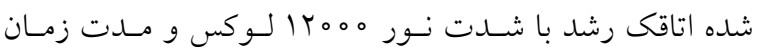

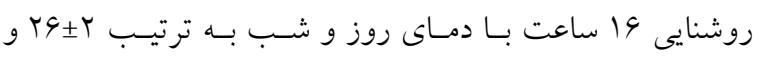

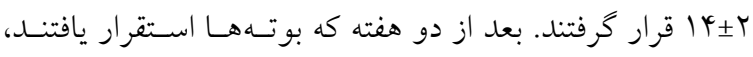

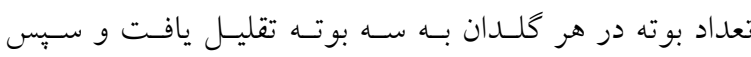

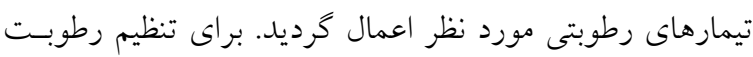
از روش توزين كلدان ها استفاده شد و براى تنظيم دقيق ميـزان

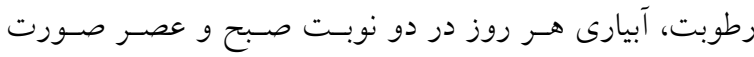

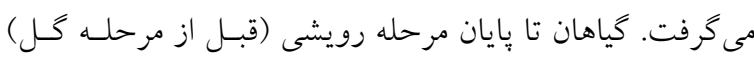

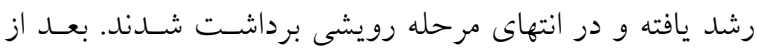

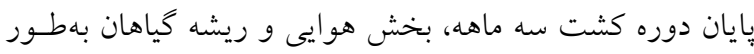

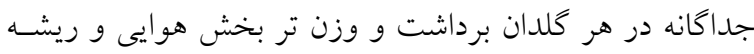

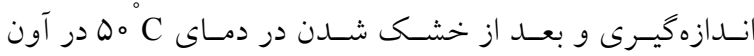
فندار، وزن خشك آنها نيز تعيين شد.

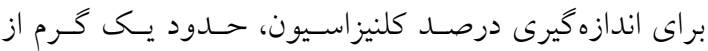
ريشههاى ريز باقىمانده در خاك كلدانها را جدا كرده و يس از

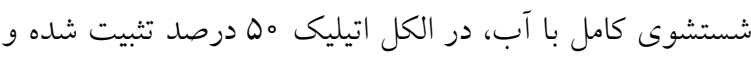

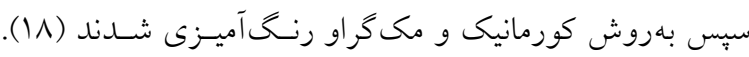
درصد كلنيزاسيون ريشه بهروش تقـاطع خطـوط شـبكه تعيسين

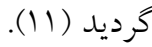

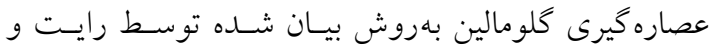

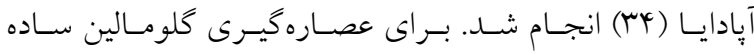
استخراج (EEG) ، يكى گرم خاك (عبور داده شــه از غربـال r ميلى متر) را داخل لوله سانتريفوز قرار داده و ^ميلى ليتر محلول

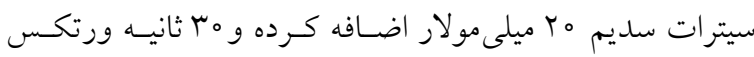

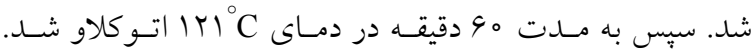

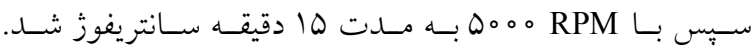
محلول صاف روئى برداشته شد. جهت استخر اج كلومـالين كـل

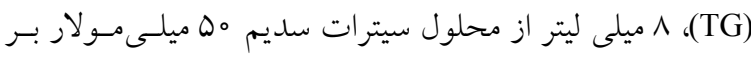

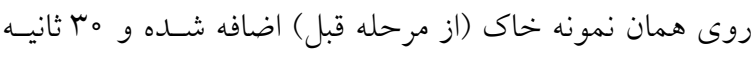
ورتكس شد. بقيه مراحل مشـابه اسـتخراج EEG بـود. محلـول

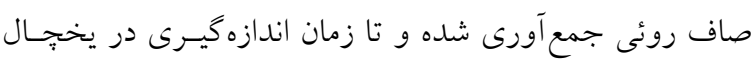

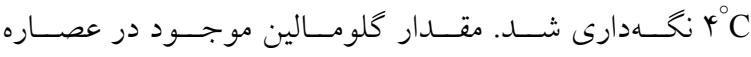

كلدان كه شامل اسبور، هيف، ريشههاى ميكوريزى و خاك بود،

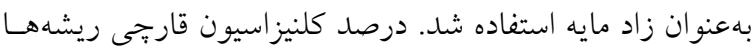

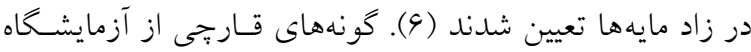

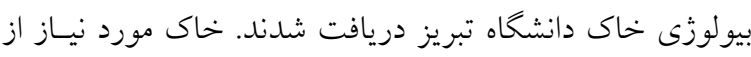

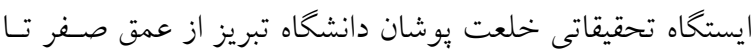

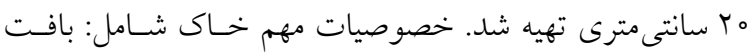

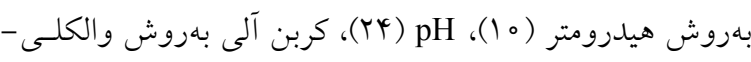

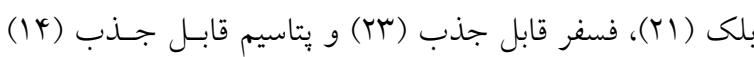

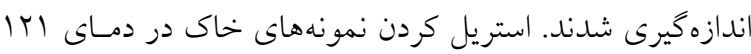

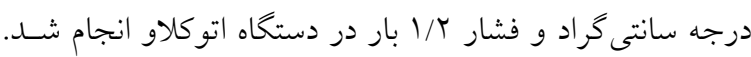

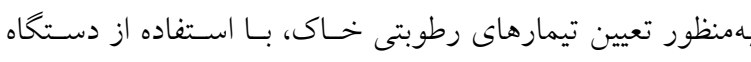

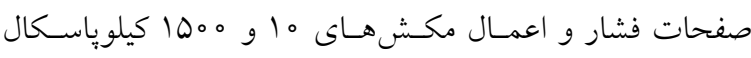

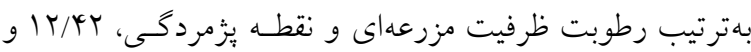

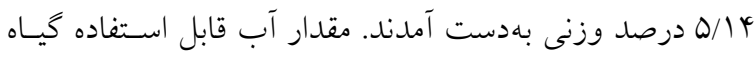
از حاصل تفاضـل ايـن دو درصــ رطوبـت محاسـبه مسى شــود.

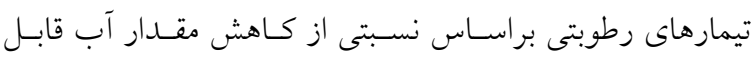

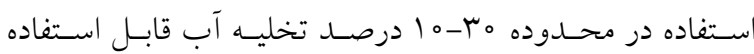

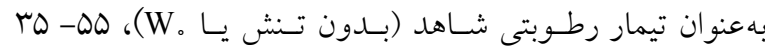
درصد تخليه آب قابل استفاده (تنش متوسط يـا ,W) و و4-90 درصد تخليه آب قابل اسـتفاده (تــش شـديد يـا W W ) تعيسين شدند. بذرها ابتدا به وسيله هييو كلريت سديم نيم درصد استريل سطحى شدند و سبّس براى جوانهزنى در داخـل كاغـــ صـافى مرطوب با آب مقطر استريل در تاريكى قرار داده شدند.

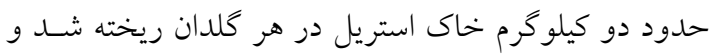

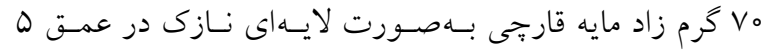

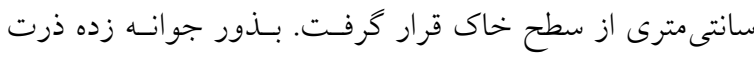
(Zea mays L.) كلدان كشت كرديد. عناصر غذايى نيتروزن و يتاسـيم براسـاس آزمون خاك و توصيه كودى منطقـه بــراى گيـاه ذرت، بـهــور

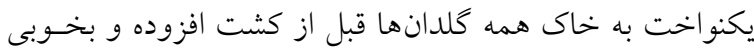
مخلوط شد (Y). در هنگام كاشت بذور، رطوبت تمامى كلدانها

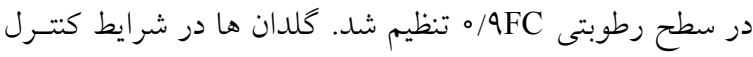


نشريه علوم آب و خاى (علوم و فنون كشاورزى و منابع طبيعى) / سال بيست و يك / شماره يك/ بهار وهـا

جدول ا. برخى ويزگى هاى خاى مورد مطالعه

\begin{tabular}{|c|c|c|c|c|c|c|c|c|}
\hline يتاسيم & فسفر & $\mathrm{dS} \mathrm{m} \mathrm{m}^{-1} \mathrm{ECe}$ & $(1: 1) \mathrm{pH}$ & كربن آلى (٪) & (\%) PWP & $(\% \mathrm{FC}$ & $\left(\mathrm{g} \mathrm{cm}^{-r}\right) \rho_{\mathrm{b}}$ & كلاس بافت خاى \\
\hline \multicolumn{2}{|c|}{$\mathrm{mg} \mathrm{kg}^{-1}$} & & & & & & & \\
\hline $1 \Lambda Y / 9$ & $\varphi / \varphi$ & $1 / 4$ & $\mathrm{~V} / \mathrm{\Lambda} I$ & O/YYI & $Q / /{ }^{\varphi}$ & $I Y / K Y$ & $1 / 4$ & شن لومى \\
\hline
\end{tabular}

جدول r. تجزيه واريانس اثر سطوح رطوبتى و گونهاى قارجى بر وزن خشك گياه و درصد كلنيزاسيون ريشه

\begin{tabular}{|c|c|c|c|c|}
\hline \multicolumn{5}{|c|}{ ميانخين مربعات } \\
\hline كلنيز اسيون & وزن خشك ريشه & وزن خشك هوايى & درجه آزادى & منبع تغيير \\
\hline $10 N / O \Lambda \Lambda^{\mathrm{ns}}$ & $\| \mu / \Lambda \psi \Lambda^{* *}$ & $90 / 01 r^{*}$ & $r$ & سطوح رطوبتى \\
\hline VIFr/TG ** & r/ATQ & $4 q / 9 \wedge 4^{*}$ & r & قارج \\
\hline $91 / 990 \mathrm{~ns}$ & $\mid / Y Y I^{\mathrm{ns}}$ & $9 / 09 \wedge^{\mathrm{ns}}$ & 9 & سطوح رطوبتى × قارج \\
\hline $90 / V Q 1$ & $1 / 191$ & $G / T \Delta \Lambda$ & me & خطاى آزمايشى \\
\hline$T r / T Q$ & rq/r & (T/Tr & - & ضريب تغييرات/ \\
\hline
\end{tabular}

\section{وزن خشك بخش هوايى و ريشه}

اثرات اصلى هر دو فاكتور قارج و رطوبت خاك بر وزن خشك بخش هوايى و ريشه معنى دار ولى اثرات متقابل فاكتورهـا غيرمعنسى دار بــود

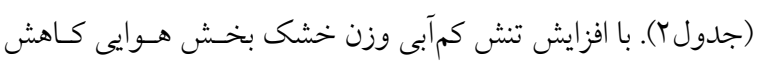

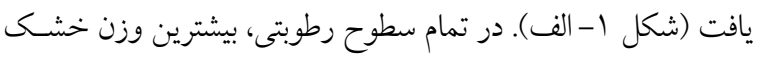

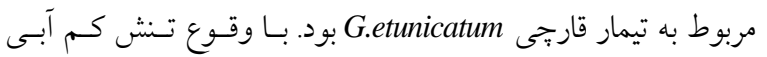

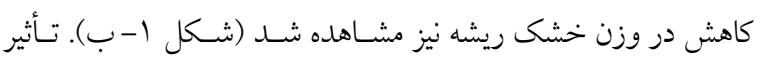

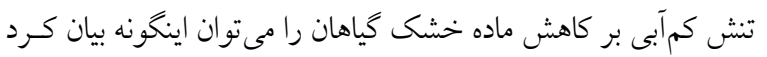

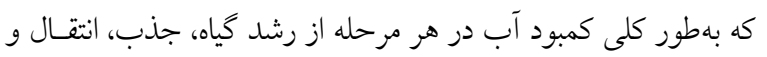

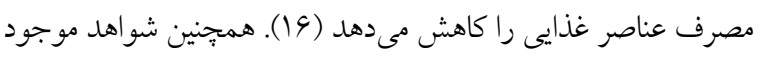

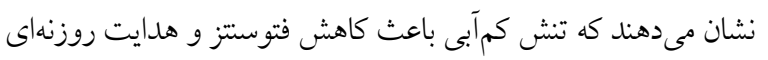

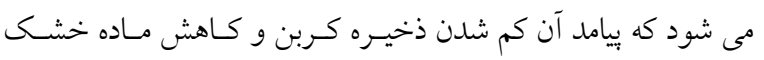

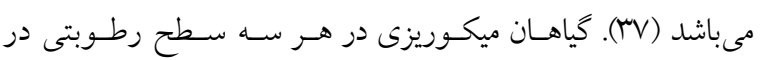

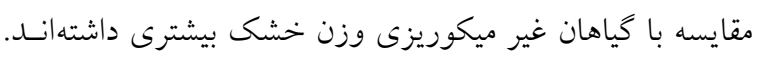

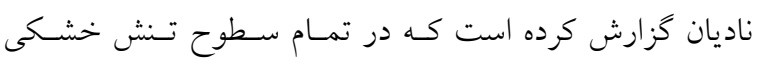

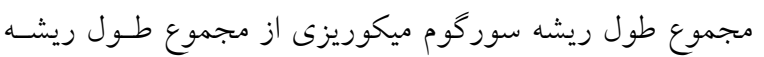

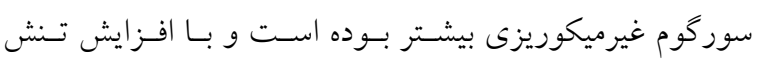

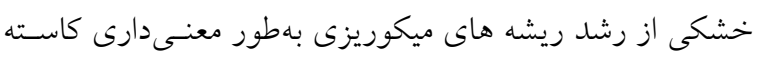
شده است (ه). (ه) - (ه)
صاف با استفاده از روش بردفورد (^) و استانداردهاى آلبـومين سرم كاوى در طول موج ه9ه نانومتر اندازهخيرى شد.

طرح آزمايشى و تجزيه آمارى

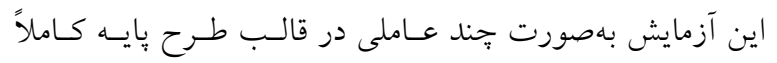

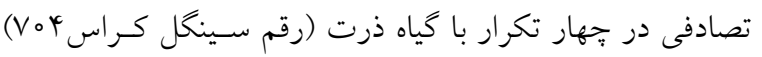

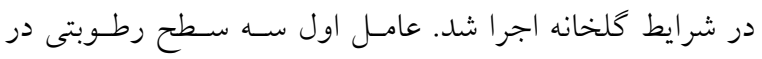

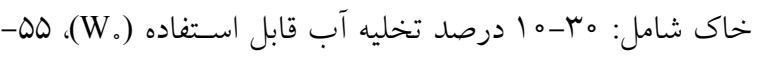

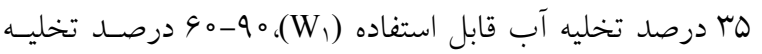

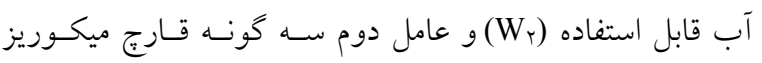
،G.intraradices (Gi) ، ، G.etunicatum (Ge)

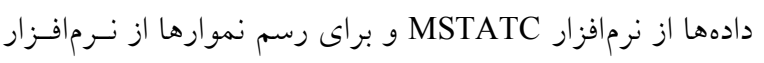

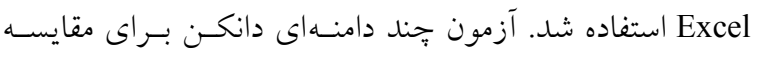

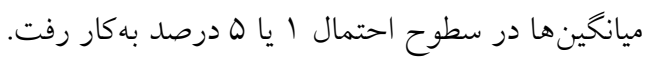

\section{نتايج و بحث}

برخى خصوصيات فيزيكى و شيميايى خاك مـورد آزمـايش در

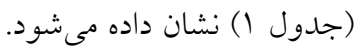



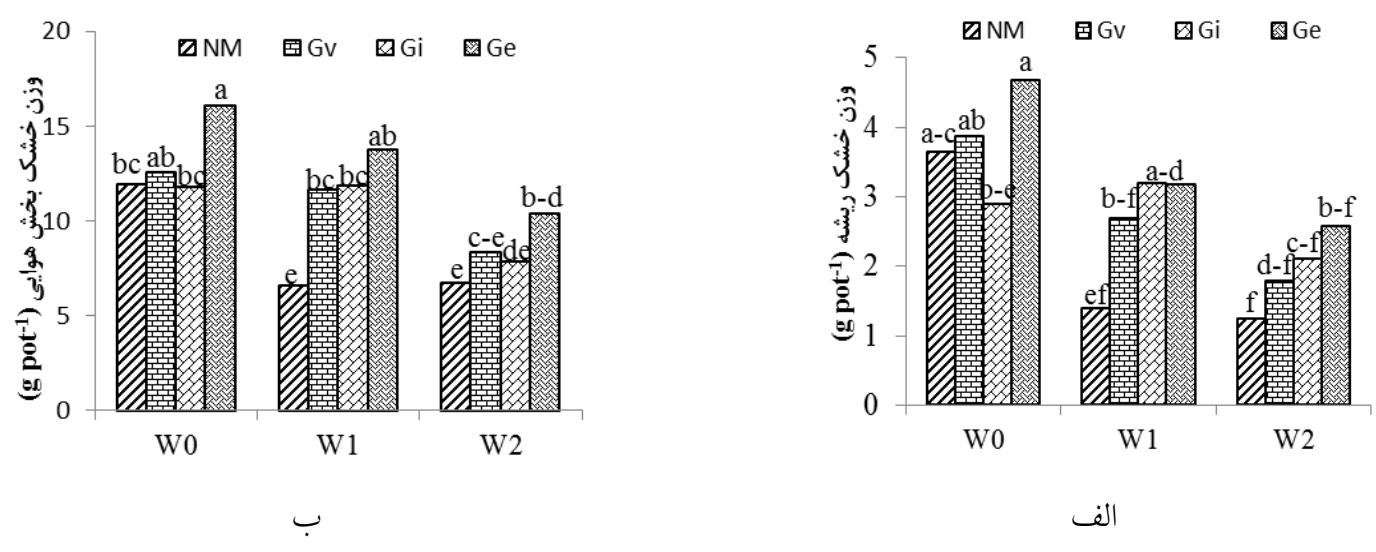

شكل ا. اثر متقابل قارج ميكوريز و رطوبت خاك بر (الف) وزن خشك بخش هوايى (ب) وزن خشك بخش ريشه

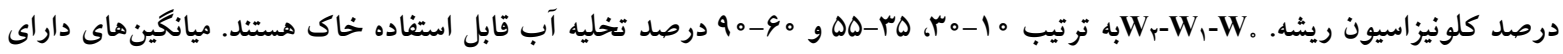
حروف مشترى از لحاظ آمارى در سطح احتمال هـ درصد معنىدار نيستند.

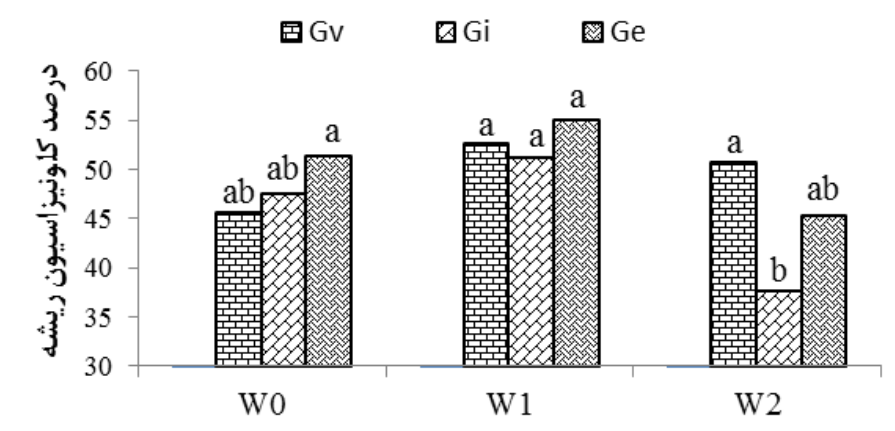

شكل r. اثر متقابل قارج ميكوريز و رطوبت خاك بر درصد كلونيزاسيون ريشه

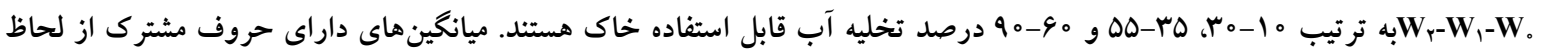

$$
\text { آمارى در سطح احتمال ه درصد معنى دار نيستند. }
$$

كردهاند كه تنش كمآبى سبب افزايش درصد كلونيزاسيون ريشـه

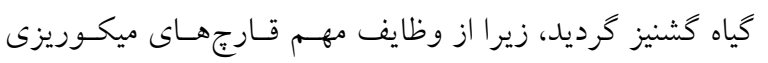
مى توان به افزايش جذب آب در شـر ايط خشـكى اشـاره نمـود

غلظت كلومالين ساده استخراج و كلومالين كل در خاى نتايج تجزيه واريانس دادهها نشـان داد كـه اثـر اصـلى سطوح

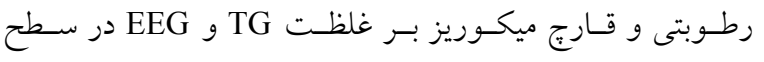

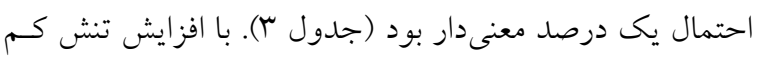

اثر اصسلى رطوبـت خــاك بـر درصــ كلونيزاسـيون ريشـهـ غيرمعنى دار ولى اثر اصلى قارج ميكوريز بر آن در سطح احتمال

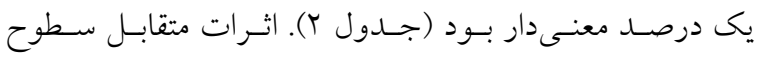

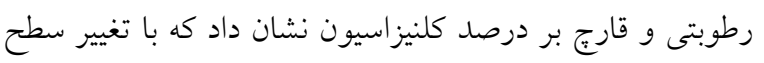

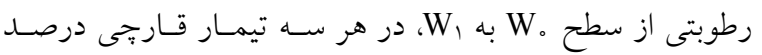

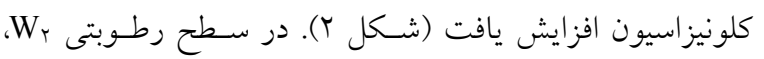
كاهش در درصد كلونيزاسيون مشاهده شد ولى معنسى دار نبـود.

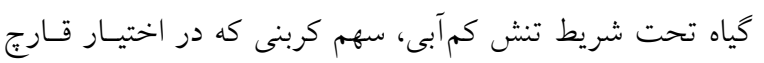

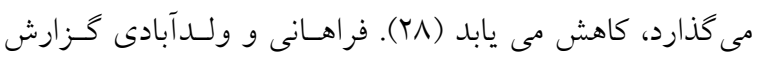



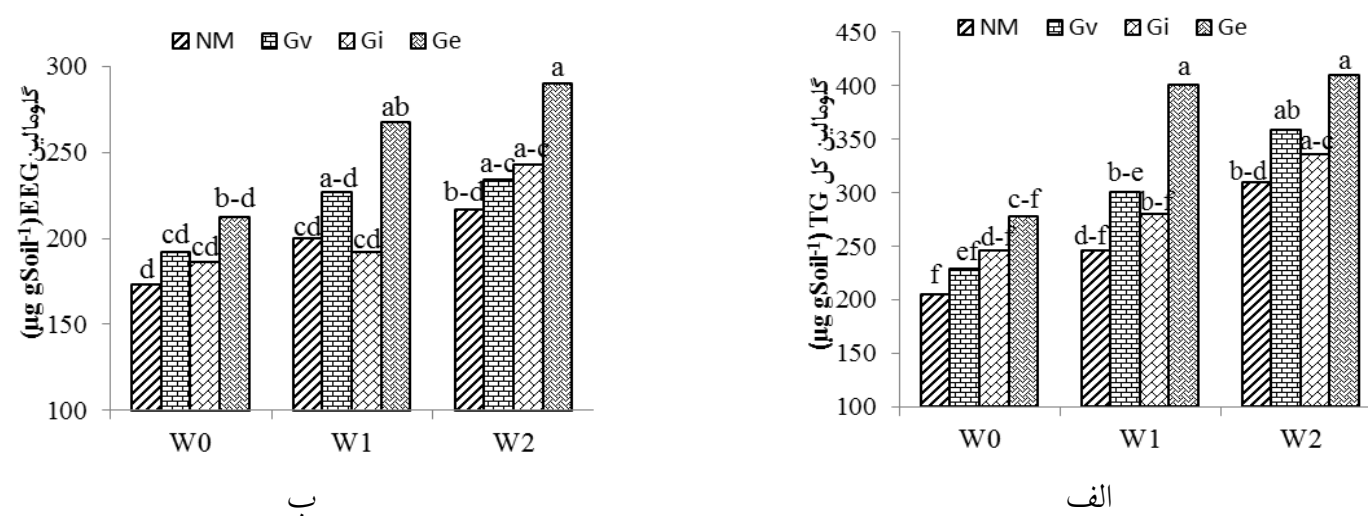

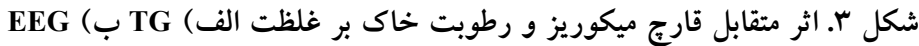

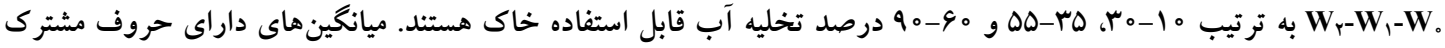
از لحاظ آمارى در سطح احتمال ه درصد معنىدار نيستند.

جدول ب. تجزيه واريانس اثر سطوح رطويتى و گونهاى قارجى بر غلظت گلومالين ساده استخراج (EEG) و كل(TG)

\begin{tabular}{|c|c|c|c|}
\hline \multicolumn{4}{|c|}{ ميانخين مربعات } \\
\hline TG & EEG & درجه آزادى & منبع تغيير \\
\hline OYYQY/QGYR* & $|r| \ll Q / 09 \Lambda^{* *}$ & r & سطوح رطوبتى \\
\hline$r Q \circ \nvdash \varphi / \mu \circ \Lambda^{* *}$ & Arrq/०99* & r & قارج \\
\hline $1 \vee 99 / 9 \circ r^{\mathrm{ns}}$ & $9 \Lambda \circ / \mathrm{rV}_{0} \mathrm{~ns}$ & 9 & سطوح رطوبتى × قارج \\
\hline$r \circ q \circ / V V Y$ & IAVq/VTL & re & خطاى آزمايشى \\
\hline$|N / 0|$ & $19 / \mathrm{VA}$ & - & ضريب تغييرات \\
\hline
\end{tabular}

فرض را كه GRSP احتمالاً بـهـعنـوان بوشـش حفـاظتى بـراى هيفـهاى قارجى جهت جلـو گيرى از هــررفت آب و عناصـر غذايى در مسير رسيدن به گياه ميزبان به ويزه تحت شرايط تنش مىباشد، تأييد كنــ (Yr). در مطالعسه كـولر و همكـاران كـه در

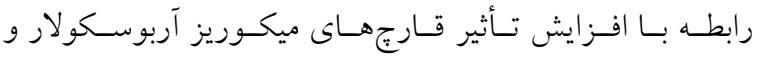
بـاكترىهـاى ريزوسـفرى محسرى رشـــ گيـاه در خـاكهـاى كشاورزى مناطق نيمهخشك تحت تـنش خشـكى و دىاكسـيد كربن زياد انجام گرفته اسـت، نتـايج نشـان داد كـه در غلظـت

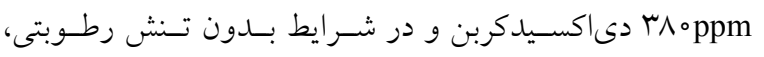
زيست تـوده كـربن ( قارجى G.intraradices است در حاليكه مقدار EEG در تيمـار
آبسى، غلظـت TG و EEG در تمـامى تيمارهـا افـزايش يافـت. بيشترين غلظت TG و EEG در هر سه تيمار رطـوبتى، مربـوط به تيمار قارجى Ge و كمترين آن مربوط به شاهد بـدون قـارج بود. در سطح رطوبتى شاهد، بين غلظت TG در تيمار شـاهد و تيمارهاى قارجى اختلاف معنى دارى مشاهده نشد، در حالى كـه با وقوع تسنش رطـوبتى، غلظـت TG در تيمـار قـارجى Ge در مقايسه با شـاهد اخـتلاف معنسى دارى داشـت و افـزايش قابـل توجهى در غلظت TG نسبت به تيمارهاى قـارجى Gv و Gi و شاهد اتفاق افتاد(شكل ب). وو و همكاران كزارش كردهانـد كـهـ تنش خشكى متوسط غلظت Glomalin-Related Soil GPRS)

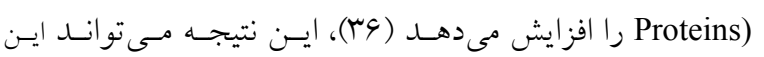



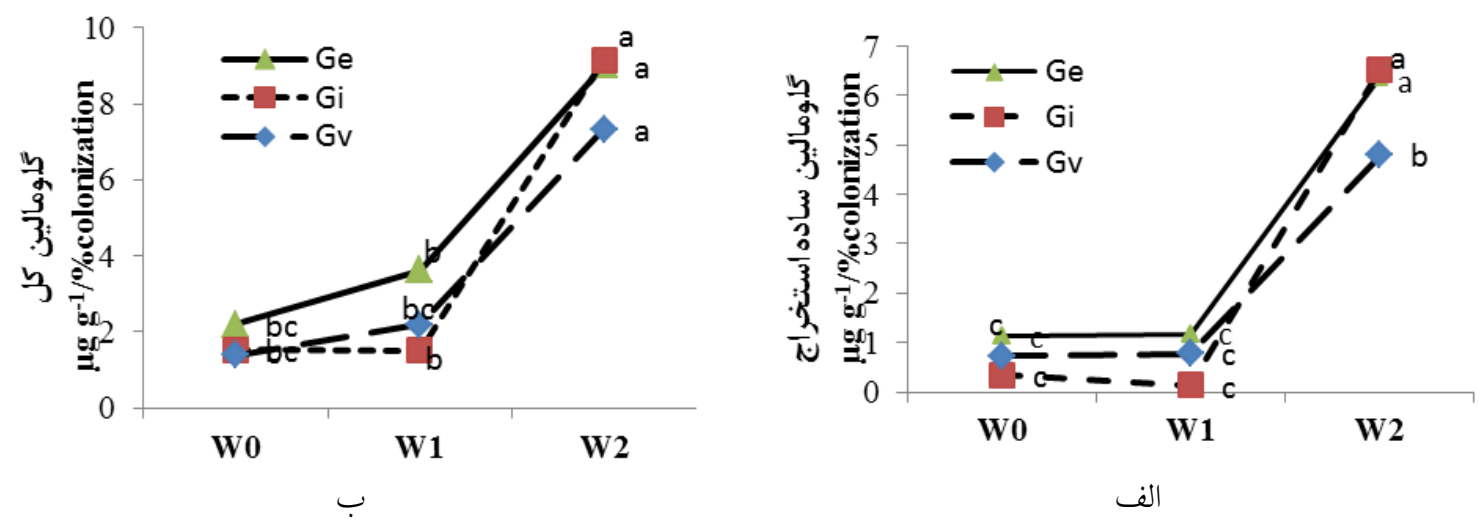

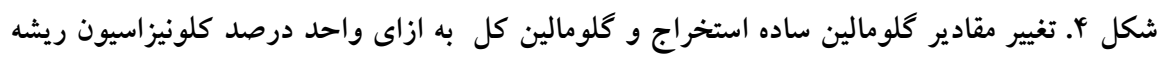

به ترتيب ه ا-ه r، هץ-W2-W1-W0

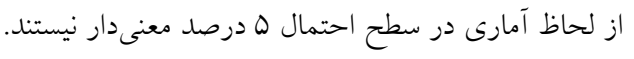

عنوان سايت اصلى براى ابراز زن كلومــالينانـــــ هويــت تـوالى

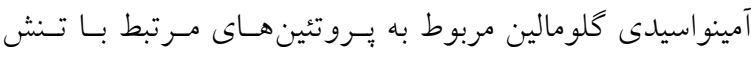

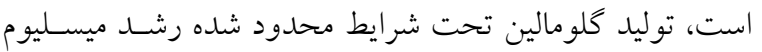

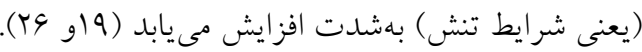

\section{نتيجه گيرى}

نتايج بهدست آمده از اين آزمايش نشان داد كه تنش كمآبسى بـر

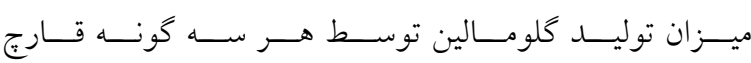
G.etunicatum ، G.intraradices ،Glomus versiforme كذاشته و باعث افزايش توليد كلومالين مى شود. اگر جه درصد

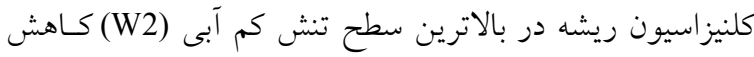

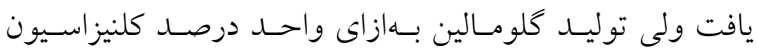

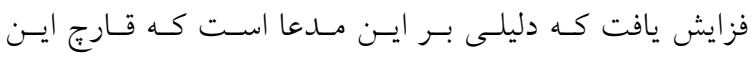

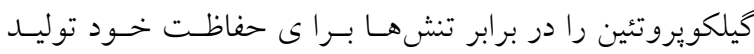

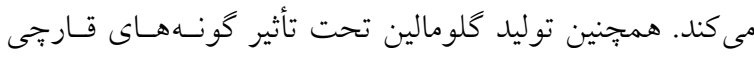

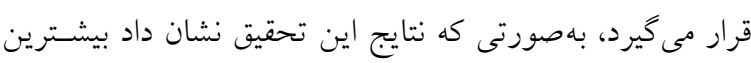

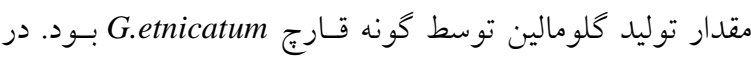

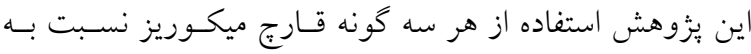

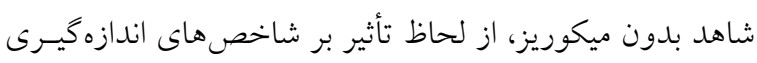

$$
\text { شده مثبت ارزيابى شد. }
$$

قارجى بيشتر از شاهد است، كـه بيـان كنــــه تخصسيص كـربن

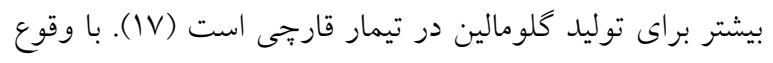
تنش رطوبتى (منفى تر شـدن يتانسـيل ماتريسك خـاك) مقــادير

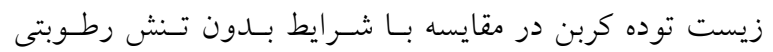

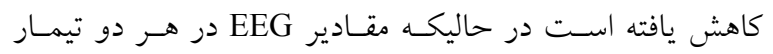

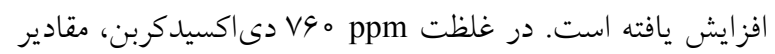
زيست توده كربن در تنش رطوبتى در مقايسه با شـرايط بــدون

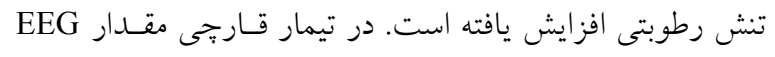

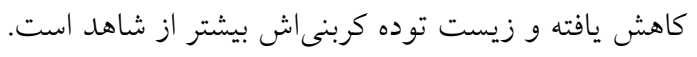

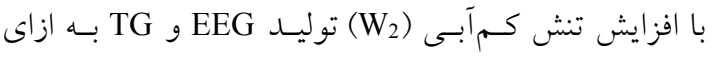

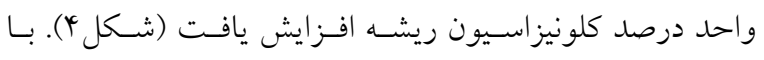

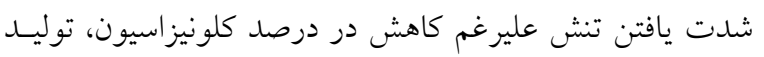

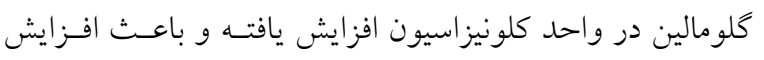

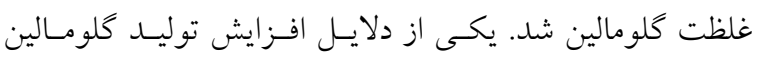

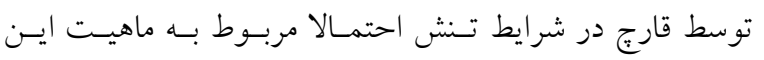

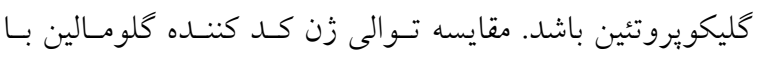

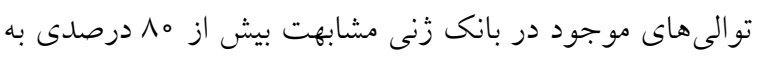

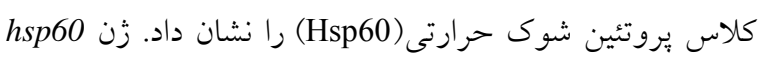
در ميسليومهاى خارج ريشهاى G.intraradices بيان مى شود و

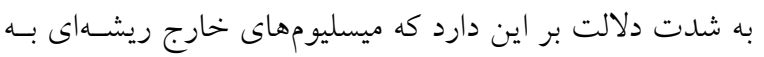




$$
\begin{aligned}
& \text { منابع مورد استفاده } \\
& \text { ا. احمدى قشلاقى، س.، ن. على اصغرزاد. وع. توسلى. بوسا. تأثير تنش شورى ناشى از كلريد سديم بـر توليـد كلومـالين توسـط }
\end{aligned}
$$

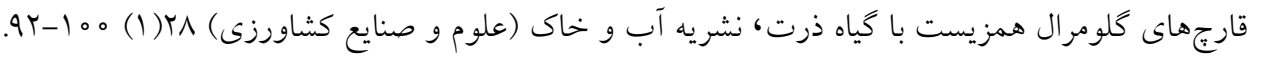

$$
\begin{aligned}
& \text { r. شعبانى زنوزق، و.، ن. على اصغرزاد . و ش. اوستان. سوها. تأثير مس بر توليد كلومالين توسط دو گونه قارج كلومرال همزيست }
\end{aligned}
$$

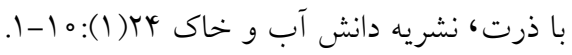

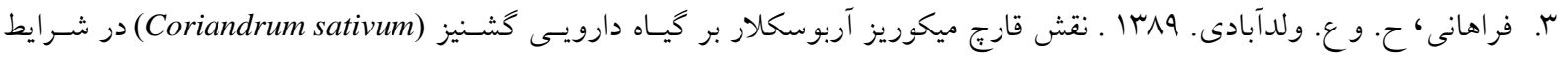

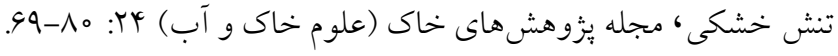

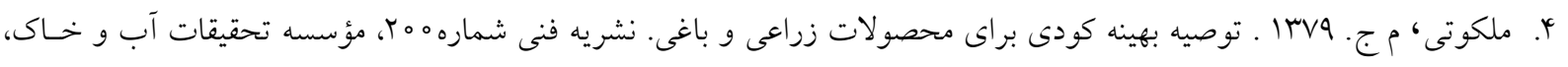

$$
\begin{aligned}
& \text { نشر آموزش كشاورزى. } \\
& \text { ه. ناديان، ح. هوبا. اثر تنش خشكى و همزيستى ميكوريزى بر رشد و جذب فسفر توسـط دو رقـم سـورگوم متفـاوت در ريخـت }
\end{aligned}
$$

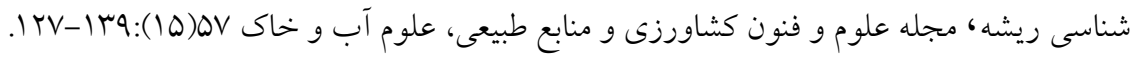

6. Aliasgharzadeh, N., N. Saleh Rastin, H. Towfighi and A. Alizadeh. 2001. Occurrence of arbuscular mycorrhizal fungal in salin soils of Tabriz Plain of Iran in relation to some physical and chemical properties of soil. Mycorrhiza 11: 119-122.

7. Blair, G. J., R. D. B. Lefroy and L. Lise.1995. Soil carbon fractions based on their degree of oxidation, and the development of a carbon management index for agricultural systems. Aust. J. of Soil Res. 36: 809-819.

8. Bradford, M. M. 1976. A dye binding assay for protein. Anal. Biochem.72: 248-254.

9. Gadkar, V. and M. C. Rillig. 2006. The arbuscular mycorrhizal fungal protein glomalin is a putative homolog of heat shok protein 60. FEMS Microbiol. Lett. 263: 93-101.

10. Gee, G. W. 2002. Particle size analysis. PP. 201-414. In: Clarke, J. H. D. et al.(Eds.) Method of soil Analysis .Part 4. Physical Methods Soil Science Society of America. Madison, Wisconsin, USA.

11. Giovannetti, M. and B. Mosse. 1980. An evaluation of techniques for measuring vesicular-arbuscular mycorrhizal infection in roots. New Phytol. 84: 489-500.

12. Gregory, J. M., J. F. B. Mitchell and A. J. Brady. 2003. Summer drought in northern midlatitudes in a timedependent $\mathrm{CO}_{2}$ climate experiment. J. Climate. 10: 662-686.

13. Gonzalez-Chavez, M. C., R. Carillo-Gonzelez., S. F. Wright. and K. A. Nichols. 2004. The role of glomalin, a protein produced by arbuscular mycorrizal fungi, in sequestering potentially toxic elements. Environ. Pollut. 130: 317-323.

14. Gupta, P. K. 2000. Soil, Pant, Water and Fertilizer Analysis. Agrobios, New Delhi, India.

15. Harle, K. J., S. M. Howden, L. P. Hunt and M. Dunlop. 2007. The potential impact of climate change on the Australian wool industry by 2030. Agric.Syst. 93: 61-89.

16. Hu, Y. and U. Schmidhalter. 2005. Drought and salinity: A comparison of their effects on mineral nutrition of plants. Plant Nut. 168: 541-549.

17. Kohler, J., F. Caravaca., M. D. M. Alguacil and A. Roldan. 2009. Elevated $\mathrm{CO}_{2}$ increases the effect of an arbuscular mycorrhizal fungus and a plant-growth-promoting rhizobacterium on structural stability of a semiarid agricultural soil under drought conditions. Soil Biol. Biochem. 41: 1710-1716.

18. Kormanik, P. P. and A. C. McGraw. 1982. Quantification of vesicular-arbuscular Mycorrhizae in plant roots. PP. 37-36. In: Schenck N. C. (Ed.), Methods and Principles of Mycorrhizal Research. The American Phytopathological Society.

19. Lovelock, C. E., S. F. Wright, D. A. Clark and R. W. Ruess. 2004a. Soil stocks of glomalin produced by arbuscular mycorrhizal fungi across a tropical rain forest landscape. Ecology. 92: 278-287.

20. Mort, A., C. Lovisolo and A. Schubert. 2000. Effect of drought stress on growth and water relation of the mycorrhizal association Helianthemum almeriense-Terfezia claveryi. Mycorrhiza. 10: 115-119.

21. Nelson, D. W. and L. E. Sommers . 1996. Total carbon, organic carbon and organic matter. PP. 961-1010 In: Sparks D. L. (Ed.), Methods of Soil Analysis. Part 3. Chemical Methods. Soil Science Society of America. Madison, Wisconsin, USA.

22. Nichols, K. A. 2008. Indirect contributions of AM fungi and soil aggregation to plant growth and protection. PP. 177-194. In: Siddiqui Z. A. et al. (Eds.), Mycorrhizae: Sustainable Agriculture and Forestry. Springer Science. 
23. Olsen, S. R. and L. E. Sommers. 1982. Phosphorus. PP. 403-430. In: Page, A. L. et al. (Eds.), Methods of Soil Analysis, Part 2. American Society of Agronomy, Soil Science Societ of America.Madison, Wisconsin.

24. Page, A. L. 1982. Methods of Soil Analysis. Part 2. Chemical and Microbiological Properties. Soil Science Society of America.

25. Rillig, M. C., G. Y. Hernandez and P. C. D. Newton. 2000. Arbuscular mycorrhizae respond to elevated atmospheric $\mathrm{CO}_{2}$ after long-term exposure: evidence from a $\mathrm{CO}_{2}$ spring in New Zealand supports the resource-balance model. Ecol. Lett. 3: 475-478.

26. Rillig, M. C. and P. D. Steinberg. 2002. Glomalin production by an arbuscular mycorrhizal fungus: a mechanism of habitat modification. Soil Biol. Biochem. 34: 1371-1374.

27. Roldan, A., L. Carrasco. and F. Caravaca. 2006. Stability of desiccated rhizosphere soil aggregates of mycorrhizal Juniperus oxycedrus grown in a desertified soil amended with a composted organic residue. Soil Biol. Biochem. 38: 2722-2730.

28. Smith, S. E. and D. J. Read. 1997. Mycorrhizal Symbiosis, $2^{\text {nd }}$ Edition. Academic Press: Sand Diego.

29. Sylvia, D. M. and S. E. Williams. 1992. Vesicular-arbuscular mycorrhizae and environmental etress. PP 101-124. In: Bethlenfalvay, G. J. and Linderman, R.G. (Eds.) Mycorrhizae in Sustainable Agriculture. American Society of Agronomy, Medison Wisconsin.

30. Wright, S. F. and R. L. Anderson. 2000. Aggregate stability and glomalin in alternative crop rotations for the central Great Plains. Biol. Fertil. Soils. 31: 249-253.

31. Wright, S. F., M. Franke-Snyder, J. B. Morton and A. Upadhyaya. 1996. Time-course study and partial characterization of a protein on arbuscular mycorrhizal hyphae during active colonization of roots. Plant and Soil. 181: 193-203.

32. Wright, S. F., V. S. Geen and M. A. Cavigelli. 2007. Glomalin in aggregate size classes from three different farming systems, Soil Till. Res. 94: 546-549.

33. Wright, S. F., M. C. Rillig and K. A. Nichols. 2000. Glomalin: a soil protein important in carbon sequestration. Abs. Papers Am. Chem. Soc. 220: 70.

34. Wright, S. F. and A. Upadhyaya. 1996. Extraction of an abundant and unusual protein from soil and comparison with hyphal protein of arbuscular mycorrhizal fungi. Soil Sci.161: 575-585.

35. Wu, Q. S. and R. X. Xia. 2006. Effect of arbuscular mycorrizal fungi on leaf solutes and root absorption areas of trifoliate orange seedlings under water stress condition. Front. Forest.China. 3: 312-317.

36. Wu, Q. S., R. X. Xia and Y. N Zou. 2008. Improved soil structure and citrus growth after inoculation with three arbuscular mycorrhizal fungi under drought stress. Europ. J. Soil Biol. 44: 122-128.

37. Yordanov, I., V. Velikova and T. Tsonev. 2003. Plant responses to drought and stress tolerance. Bulg. J. Plant Physiol. Special Issue, 187-206. 


\title{
Effects of Water Deficit Stress on Glomalin Secretion by Glomerales in Symbiosis with Corn Plant
}

\author{
M. Rishcefid, N. Aliasgharzad ${ }^{*}$ and M. R. Neyshabouri ${ }^{1}$
}

(Received: Jan. 11-2015 ; Accepted: Aug. 22-2016)

\begin{abstract}
Glomalin is a glycoprotein identified in and extracted from cell walls of hyphae and spores of Glomeral fungi. It deposites on soil particles and acts as a glue which leads to the formation and stabilization of soil aggregates. Water deficit stress by affecting mycorrizal symbiosis can alter glomalin production. This study was conducted as a factorial experiment arranged in a completely randomized design (CRD) with four replications using corn (Zea mays L. Single cross 704) under greenhouse conditions. The first factor was three levels of soil moisture including $10-30 \%\left(\mathrm{~W}_{0}\right)$, 35$55 \%\left(\mathrm{~W}_{1}\right), 60-90 \%$ depletion of available water $\left(\mathrm{W}_{2}\right)$ and the second factor was three species of mycorrhizal fungi, Glomus versiforme (Gv), Glomus intraradices (Gi), Glomus etunicatum (Ge) and non mycorrhizal control (NM). At the end of vegetative growth, easily extractable glomalin (EEG) and total glomalin (TG) were measured using the Bradford method after extraction from soil. Shoot and root dry weights and root colonization decreased by declining soil moisture level. Water deficit significantly increased the amount of EEG and TG in soil. Also, a significant increase in glomalin production was observed at $\mathrm{W}_{2}$ level in all three fungal species compared to the $\mathrm{W}_{0}$ and $\mathrm{W}_{1}$ moisture levels. Moreover, by enhancing water deficit stress and decreasing root colonization, glomalin production per unit percent of root colonization was significantly increased.
\end{abstract}

Keywords: Carbon dynamics, Corn, Glomeral fungi, Glomalin, Water deficit stress

1. Dept. of Soil Sci., Faculty of Agric., Univ. of Tabriz, Tabriz, Iran.

*: Corresponding Author, Email: n-aliasghar@tabrizu.ac.ir 